\title{
ADOPSI TEKNOLOGI SISTEM INFORMASI AKUNTANSI MELALUI PEMANFAATAN ZAHIR ACCOUNTING (STUDI KASUS : PT. ANEKA SISTIM INFORMASI BOGOR)
}

\author{
Eni Heni Hermaliani ${ }^{1)}$, Devy Narulyta ${ }^{2)}$ \\ ${ }^{1,2)}$ Program Studi Komputerisasi Akuntansi, AMIK BSI Bogor \\ 1) eni heni@bsi.ac.id, ${ }^{2)}$ dnarulyta@gmail.com
}

\begin{abstract}
PT. Aneka Sistim Informasi is a company engaged in trade and services, in which the process of processing and application of financial transaction data is still using conventional system. Through this research the authors describe the outline of accounting information using Zahir Accounting application. Accounting information system is a computer-based system that includes the transaction processing cycle, the use of information technology and information system development. The purpose of this research is to facilitate data entry transaction and financial reporting using accounting program applications. While the data collection method used is a direct observation of transactions that occur in the daily activities of business process activities, then do the interview on the Store Manager and Administration. The literature review studies complement two previous data collection techniques to strengthen theoretically. The result of data processing by using the application of accounting program starts from data entry by doing initial setup, beginning balance, master data up to transaction entry. Thus it will automatically generate the necessary financial statements to be more effective and efficient in making financial statements and facilitate the decision-making process.
\end{abstract}

Keywords : Technology Adoption, Accounting Information System, Zahir Accounting

\section{PENDAHULUAN}

Manfaat teknologi informasi dalam membantu pengolahan data keuangan pada suatu organisasi atau perusahaan adalah efisiensi, penghematan waktu dan biaya serta ruang penyimpanan akan mempermudah pengarsipan serta pengambilan data kembali untuk menghasilkan informasi yang berguna dalam mengambil keputusan. Segala bentuk transaksi harus dicatat kedalam suatu media pencatat yang disebut dengan jurnal sehingga kegiatan akuntansi membutuhkan waktu yang cukup lama dan data yang diolah dapat terjadi kesalahan sehingga penyediaan informasi keuangan tersebut memerlukan biaya yang relatif lebih besar jika harus dikerjakan secara manual yang bersifat konvensional. Namun akan berbeda apabila proses pengolahan data tersebut sudah menggunakan aplikasi program akuntansi (Himayati, 2008). PT. Aneka Sistim Informasi masih menggunakan sistem manual mulai dari memproses data transaksi hingga pembuatan laporan keuangannya. Hal ini masih dirasakan kurang efektif dan efisien. Dalam penelitian ini, penulis mencoba mengaplikasikan kegiatan pengolahan data akuntansi dari mulai menginput transaksi sampai dengan membuat laporan keuangan menggunakan perangkat lunak Zahir Accounting. Perangkat ini merupakan software akuntansi keuangan berbahasa Indonesia dimana lebih fleksibel, berfasilitas lengkap dan berdaya guna tinggi yang dirancang dengan tepat sesuai kebutuhan usaha kecil menengah. Dengan demikian tujuan dari penelitian ini adalah mempermudah penginputan data transaksi dan pembuatan laporan keuangan yang menjadi alternatif solusi bagi PT. Aneka Sistim Informasi.

\section{TINJAUAN PUSTAKA}

Sistem informasi menurut Leitch dan Davis adalah suatu sistem di dalam suatu organisasi yang mempertemukan kebutuhan pengolahan transaksi harian, mendukung 
kegiatan operasi sehari-hari, bersifat manajerial dan kegiatan suatu organisasi dan menyediakan pihak-pihak tertentu dengan laporan-laporan yang diperlukan (Puspitawati, Lilis, Sri Dewi Anggadini, 2011)

Sedangkan Sistem Informasi Akuntansi menurut Bodnar dan Hapwood sebagai : ... seperangkat sumber daya berupa manusia dan peralatan yang dirancang untuk mentransformasikan data keuangan dalam bentuk informasi yang dibutuhkan oleh para pengambil keputusan. (Manurung, Elvy Maria, 2011)

Pengertian Akuntansi menurut (Himayati, 2008) "Akuntansi adalah proses pengidentifikasian, pengolongan, penyortiran, pengikhtisaran, dan penyajian transaksi keuangan (informasi ekonomi), sehingga dapat dilakukan penilaian dan pengambilan keputusan oleh pemakai informasi tersebut". Adapun siklus akuntansi adalah menggambarkan proses pengidentifikasian bukti transaksi, pencatatan transaksi ke dalam jurnal umum (posting ke general ledger), pengelompokan bukti-bukti transaksi ke dalam golongan transaksi yang sama ke dalam buku besar (ledger), meringkas bukti transaksi ke dalam neraca saldo (trial balance). Melakukan peyesuaian (adjustment), membuat kertas kerja (worksheet) dan membuat laporan keuangan (financial statement) (Puspitawati, Lilis, Sri Dewi Anggadini, 2011)

Berdasar Standar Akuntansi Keuangan yang diterbitkan oleh Ikatan Akuntansi Indonesia (Fitria, Dina, 2014) bahwa : "Tujuan laporan keuangan adalah menyediakan informasi yang menyangkut posisi keuangan, kinerja, serta perubahan posisi keuangan suatu perusahaan yang bermanfaat bagi sejumlah besar pemakai dalam pengambilan keputusan."

Berkaitan dengan aplikasi program akuntansi salah satunya Zahir Accounting merupakan sebuah program akuntansi yang di desain khusus untuk mengelola keuangan perusahaan secara mudah, fleksibel, yang berfasilitas lengkap dan dapat digunakan untuk berbagai macam perusahaan, baik perusahaan jasa maupun perusahaan dagang (Himayati, 2008). Adapun keunggulan perangkat lunak tersebut yaitu dari sisi kemudahan dalam bahasa yang disertai Bahasa Indonesia dalam sehari-hari, kemudahan dalam penggunaan yang simple, sistem akuntansi berstandar Indonesia dengan System Double Entry, kemudahan mencetak faktur pajak dan standar, memiliki nilai transaksi sebanyak 15 digit, memiliki fasilitas Giro Mundur dan harga murah.

\section{METODE PENELITIAN}

Penelitian ini memerlukan data sebagai bahan dasar untuk melakukan pemrosesan, dimana metode yang digunakan untuk mengumpulkan data bahan masukan, antara lain :

1. Metode Pengamatan (Observation Method), yaitu melakukan pengamatan langsung tentang transaksi akuntansi yang. Hasil pengamatan diketahui bahwa metode yang dilakukan pada perusahaan tersebut masih menggunakan sistem manual, dimana pengolahan datanya masih banyak yang rangkap, penyimpanan dokumen memerlukan tempat yang cukup banyak sehingga masih belum efisien.

2. Metode Wawancara (Interview Method), yaitu mewawancarai karyawan perusahaan pada bagian store manager dan staf administrasi keuangan untuk mengetahui proses yang terjadi dari mulai pembelian, penjualan barang hingga terbitnya dokumendokumen yang digunakan sebagai bukti transaksi dalam pembukuan akuntansi.

3. Metode Kepustakaan (Library Method), yaitu kajian melalui buku terkait dengan akuntansi dagang dan aplikasi Zahir Accounting serta referensi jurnal penelitian ilmiah melalui online untuk melengkapi teori pendukung dalam penelitian ini. 


\section{HASIL DAN PEMBAHASAN}

\subsection{Analisis}

\section{Tinjauan Perusahaan}

PT. Aneka Sistim Informasi merupakan perusahaan yang bergerak dibidang perdagangan gadget dan jasa service yang beralamat J1. Jend. Sudirman No. 58 G RT 01/03 Kelurahan Sempur Kecamatan Bogor Tengah Kota Bogor dengan Surat Izin Usaha Perdagangan (SIUP) Nomor : 517/565/PK/B/BPPTPM/IX/2015 dan NPWP : 21.152.854.2.404.000. Berdiri sejak tahun 2000 dengan memulai layanannya dan mengembangkan divisi yang berkecimpung dalam penyediaan komputer dan perlengkapannya. Kemudian meningkat pada penyedia produk atau barang teknologi informasi dan komunikasi yang handal dan berkualitas.

\section{Tinjauan Kasus}

Permasalahan yang dihadapi perusahaan saat ini pengolahan data akuntansi masih dilakukan secara konvensional yaitu hanya menggunakan Microsoft Excel, mulai dari tata kelola administrasi penjualan sampai laporan keuangan. Salah catat dan perbedaan data antara copy invoice dengan data di Microsoft Excel menjadi masalah yang sering dihadapi, sehingga data yang dihasilkan kurang memuaskan atau kurang maksimal dan menjadikan proses pembuatan laporan menjadi lama dan tidak efisien.

Melalui penelitian ini, mencoba menerapkan (mengadopsi) penggunaan program aplikasi akuntansi dengan menggunakan software Zahir Accounting 5.1 mulai dari proses penjurnalan sampai dengan pembuatan laporan. Hal ini diharapkan menjadi solusi untuk mendukung jalannya proses pengolahan data sehingga diperoleh hasil yang lebih baik.

\section{Bukti Pencatatan Akuntansi}

Sebelum mengolah data ke dalam aplikasi komputer akuntansi dilakukan inventarisasi sebagai bentuk masukan dengan pengumpulan bukti transaksi, pembuatan jurnal, posting buku besar, selanjutnya pembuatan neraca saldo. Adapun periode yang sudah terdata adalah tahun Februari 2017 meliputi saldo awal, data supplier, data customer, data karyawan, data barang dan saldo persediaan, data aktiva tetap, data transaksi bulan Maret 2017, jurnal umum, buku besar kas, buku besar bank, buku besar persediaan barang dagang, buku besar perlengkapan, buku besar peralatan, buku besar akumulasi penyusutan peralatan, buku besar kendaraan, buku besar akumulasi penyusutan kendaraan, buku besar modal, buku besar penjualan, buku besar pendapatan service, buku besar HPP, buku besar biaya iklan, buku besar biaya administrasi, buku besar biaya transportasi, buku besar biaya keamanan, neraca saldo sebelum penyesuaian, jurnal penyesuaian, neraca lajur, laporan laba rugi, laporan perubahan ekuitas, neraca. Adapun pencatatan akuntansi dapat dilihat pada Tabel 1 Neraca Saldo, Tabel 2 Jurnal Penyesuaian, Tabel 3 Neraca Lajur, sebelum dilakukannya penyusunan laporan keuangan yang meliputi Laporan Laba Rugi, Laporan Perubahan Ekuitas dan Neraca. 
Tabel 1. Neraca Saldo

\begin{tabular}{|c|c|c|c|}
\hline \multicolumn{4}{|c|}{$\begin{array}{c}\text { PT. Aneka Sistim Informasi } \\
\text { Neraca Saldo } \\
\text { Maret } 2017\end{array}$} \\
\hline No. Akun & Nama Akun & Debet & Kredit \\
\hline $110-20$ & Kas & 81.605 .800 & \\
\hline $120-10$ & Bank & 41.550 .000 & \\
\hline $140-10$ & Persediaan Barang Dagang & 87.778 .500 & \\
\hline $150-20$ & Perlengkapan & 1.381 .700 & \\
\hline $170-30$ & Peralatan & 21.400 .000 & \\
\hline $170-31$ & Alcm. Peny. Peralatan & & 2.007 .000 \\
\hline $170-50$ & Kendaraan & 138.000 .000 & \\
\hline $170-51$ & Alcm. Peny. Kendaraan & & 13.455 .000 \\
\hline $310-20$ & Moda1 & & 345.074 .500 \\
\hline $410-10$ & Penjualan & & 36.095 .000 \\
\hline $410-91$ & Pendapatan Service & & 5.660 .000 \\
\hline $510-10$ & HPP & 30.110 .500 & \\
\hline $610-50$ & Biaya Iklan & 60.000 & \\
\hline $610-60$ & Biaya Administrasi & 90.000 & \\
\hline $610-61$ & Biaya Transportasi & 150.000 & \\
\hline $610-62$ & Biaya Keamanan & 165.000 & \\
\hline & TOTAL & 402.291 .500 & 402.291 .500 \\
\hline
\end{tabular}

Tabel 2. Jurnal Penyesuaian

\begin{tabular}{|c|c|c|c|c|}
\hline \multicolumn{5}{|c|}{$\begin{array}{l}\text { PT. Aneka Sistim Informasi } \\
\text { Jurnal Penyesuaian } \\
\text { Maret } 2017\end{array}$} \\
\hline Tanggal & Keterangan & Ref & Debet & Kredit \\
\hline \multirow[t]{2}{*}{$31 / 03 / 2017$} & Biaya Peny. Mesin dan Peralatan & & 319.500 & \\
\hline & Alm. Peny. Mesin dan Peralatan & & & 319.500 \\
\hline \multirow[t]{2}{*}{$31 / 03 / 2017$} & Biaya Peny. Kendaraan & & 1.035 .000 & \\
\hline & Alm. Peny. Kendaraan & & & 1.035 .000 \\
\hline \multicolumn{2}{|r|}{ Total } & & 1.354 .500 & 1.354 .500 \\
\hline
\end{tabular}

Tabel 3. Neraca Lajur

$$
\begin{gathered}
\text { PT. Aneka Sistim Informasi } \\
\text { Neraca Lajur } \\
\text { Maret } 2017
\end{gathered}
$$

\begin{tabular}{|c|c|c|c|c|c|c|c|c|c|c|}
\hline \multirow{2}{*}{ Nama Akun } & \multicolumn{2}{|c|}{ Neraca Saldo } & \multicolumn{2}{|c|}{ Penyesuaian } & \multicolumn{2}{|c|}{ Neraca Sisa Disesuaiakan } & \multicolumn{2}{|c|}{ Laba Rugi } & \multicolumn{2}{|c|}{ Neraca } \\
\hline & Debet & Kredit & Debet & Kredit & Debet & Kredit & Debet & Kredit & Debet & Kredit \\
\hline Kas & 81.605 .800 & & & & 81.605 .800 & & & & 81.605 .800 & \\
\hline Bank & 41.550 .000 & & & & 41.550 .000 & & & & 41.550 .000 & \\
\hline \multicolumn{11}{|l|}{ Pivtang Usaha } \\
\hline Persediaan Barang Dagan & 87.778 .500 & & & & 87.778 .500 & & & & 87.778 .500 & \\
\hline \begin{tabular}{|l|} 
Perlengkapan \\
\end{tabular} & 1.381 .700 & & & & 1.381 .700 & & & & 1.381 .700 & \\
\hline Peralatan & 21.400 .000 & & & & 21.400 .000 & & & & 21.400 .000 & \\
\hline Akm. Peny. Peralatan & & 2.007 .000 & & 319.500 & & 2.326 .500 & & & & 2.326 .500 \\
\hline Kendaraan & 138.000 .000 & & & & 138.000 .000 & & & & 138.000 .000 & \\
\hline Akm. Peny. Kendaraan & & 13.455 .000 & & 1.035 .000 & & 14.490 .000 & & & & 14.490 .000 \\
\hline \multicolumn{11}{|l|}{ Hutang Usaha } \\
\hline Modal & & 345.074 .500 & & & & 345.074 .500 & & & & 345.074 .500 \\
\hline Penjualan & & 36.095 .000 & & & & 36.095 .000 & & 36.095 .000 & & \\
\hline Pendapatan Service & & 5.660 .000 & & & & 5.660 .000 & & 5.660 .000 & & \\
\hline HPP & 30.110 .500 & & & & 30.110 .500 & & 30.110 .500 & & & \\
\hline Biaya Iklan & 60.000 & & & & 60.000 & & 60.000 & & & \\
\hline Biaya Administrasi & 90.000 & & & & 90.000 & & 90.000 & & & \\
\hline Biaya Transportasi & 150.000 & & & & 150.000 & & 150.000 & & & \\
\hline \begin{tabular}{|l|} 
Bizya Keamanan \\
\end{tabular} & 165.000 & & & & 165.000 & & 165.000 & & & \\
\hline Biaya Peny. Peralatan & & & 319.500 & & 319.500 & & 319.500 & & & \\
\hline Bizya Peny. Kendaraan & & & 1.035 .000 & & 1.035 .000 & & 1.035 .000 & & & \\
\hline & 402.291 .500 & 402.291 .500 & 1.354 .500 & 1.354 .500 & 403.646 .000 & 403.646 .000 & 31.930 .000 & 41.755 .000 & 371.716 .000 & 361.891 .000 \\
\hline \multirow{2}{*}{\multicolumn{7}{|c|}{ Laba Bersih }} & 9.825 .000 & & & 9.825 .000 \\
\hline & & & & & & & 41.755 .000 & 41.755 .000 & 371.716 .000 & 371.716 .000 \\
\hline
\end{tabular}

Sumber : Hasil Olah (2017) 


\subsection{Adopsi Aplikasi Komputer Akuntansi (Zahir Accounting)}

Berikut adalah proses olah data akuntansi menggunakan aplikasi pada perusahaan:

\section{Setup Awal}

Meliputi pembuatan database perusahaan, daftar rekening, satuan pengukuran, data barang, kode supplier, kode customer, data mata uang dan akun penting, harta tetap. Pada Gambar 1 merupakan tampilan hasil akhir pengisian database perusahaan, dimulai dengan Isi nama perusahaan $>>$ Alamat perusahaan $>$ Kota $>$ Kode Pos > Klik Lanjutkan. Pada Periode Akuntansi, pilih bulan $>$ > isi tahun $>>$ pilih tutup buku akhir tahun > ganti lokasi penyimpanan. Setelah mengisi data perusahaan maka akan muncul konfirmasi akhir. Klik tombol Proses untuk memulai proses pembuatan data keuangan. Pada Konfirmasi Jenis Usaha, pilih Jenis Usaha >> klik Lanjutkan > pada jendela Information klik Yes. Selanjutnya, Setup Mata Uang Fungsional $\gg$ Pilih IDR $\gg$ Klik Lanjutkan. Klik tombol Selesai untuk menyelesaikan pembuatan data baru.

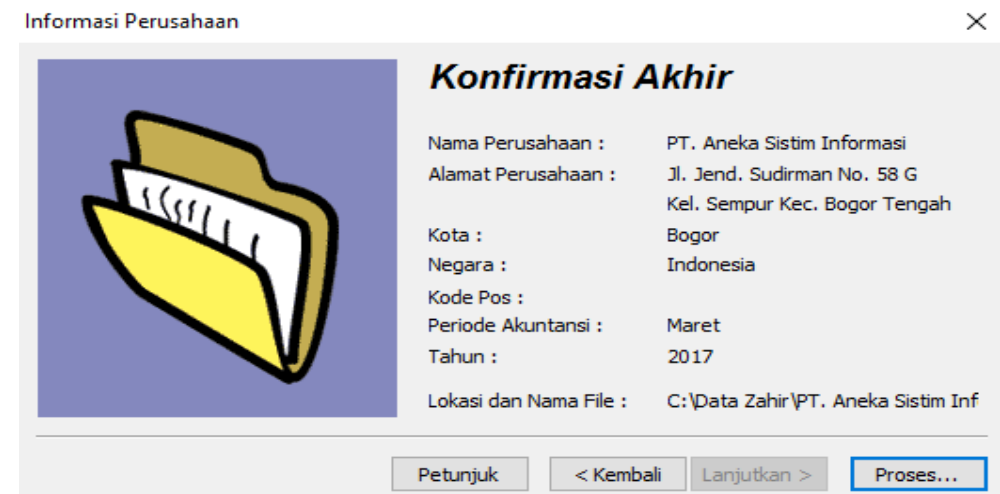

Sumber : Data Pengolahan Zahir 5.1 (2017)

Gambar 1. Tampilan Konfirmasi Akhir

Pada Gambar 2 Pilih modul Data - Data $\gg$ klik Data Rekening $\gg$ Klik Baru jika ingin membuat akun baru $\gg$ Klik Edit jika ingin mengedit akun $\gg$ Klik Hapus jika ingin menghapus akun.

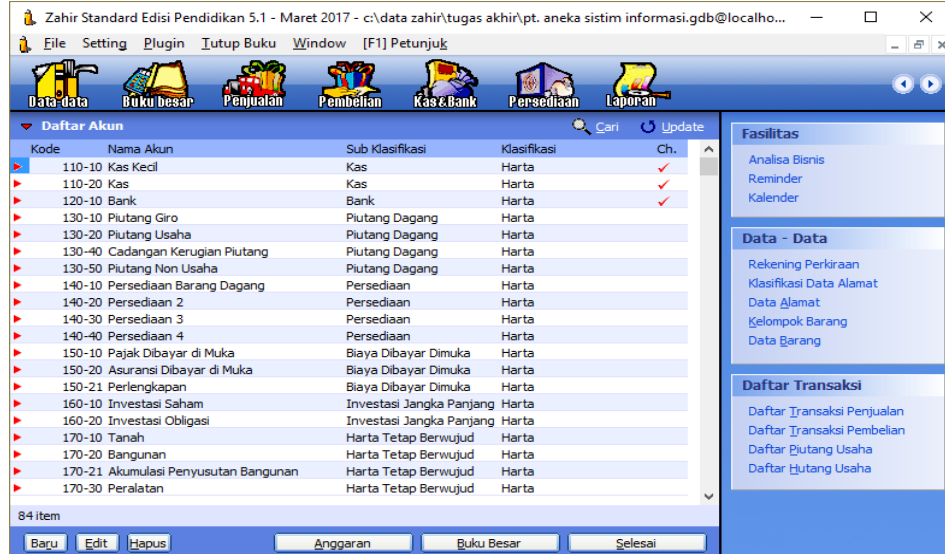

Sumber : Data Pengolahan Zahir 5.1 (2017)

Gambar 2. Daftar Rekening

Pada Gambar 3 Pilih modul Data - Data $\gg$ Klik Data Produk $\gg$ Klik Baru $\gg$ Isi Data $>$ Klik Rekam 


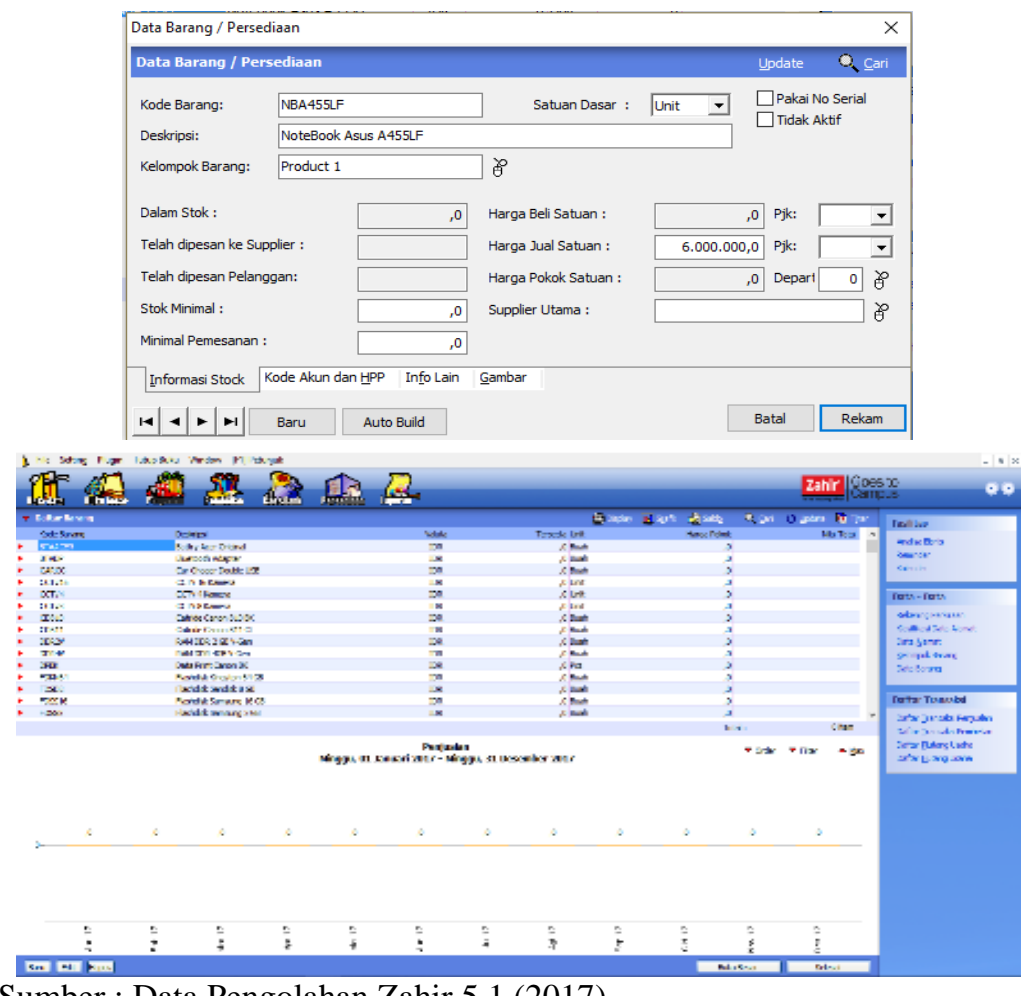

Sumber : Data Pengolahan Zahir 5.1 (2017)

Gambar 3. Membuat Data Barang Dan Tampilan Daftar Barang

Pada Gambar 4 Membuat Kelompok Harta Tetap Pilih Modul Data dan Alamat >> pilih Kelompok Harta Tetap >> klik Baru >> isikan data >> klik Rekam
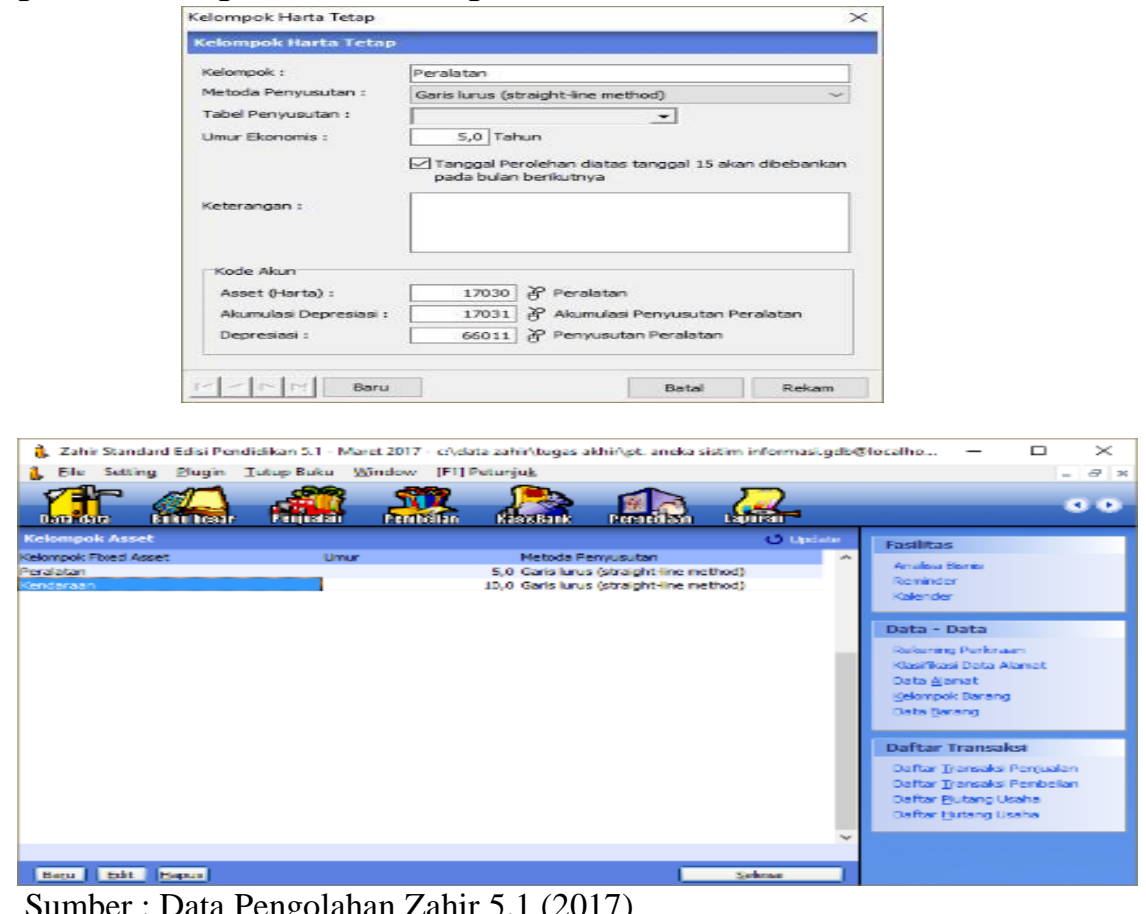

Gambar 4. Membuat Kelompok Harta Tetap Dan Daftar Kelompok Harta Tetap

\section{Input Saldo Awal}

Meliputi input saldo awal, setup persediaan, dengan instruksi seperti pada Gambar 5, Klik Setting > pilih Saldo Awal > pilih Saldo Awal Akun > klik Rekam. 
Selanjutnya Pilih Setting $>$ pilih Saldo Awal Persediaan $\gg$ klik Baru $>>$ klik Rekam

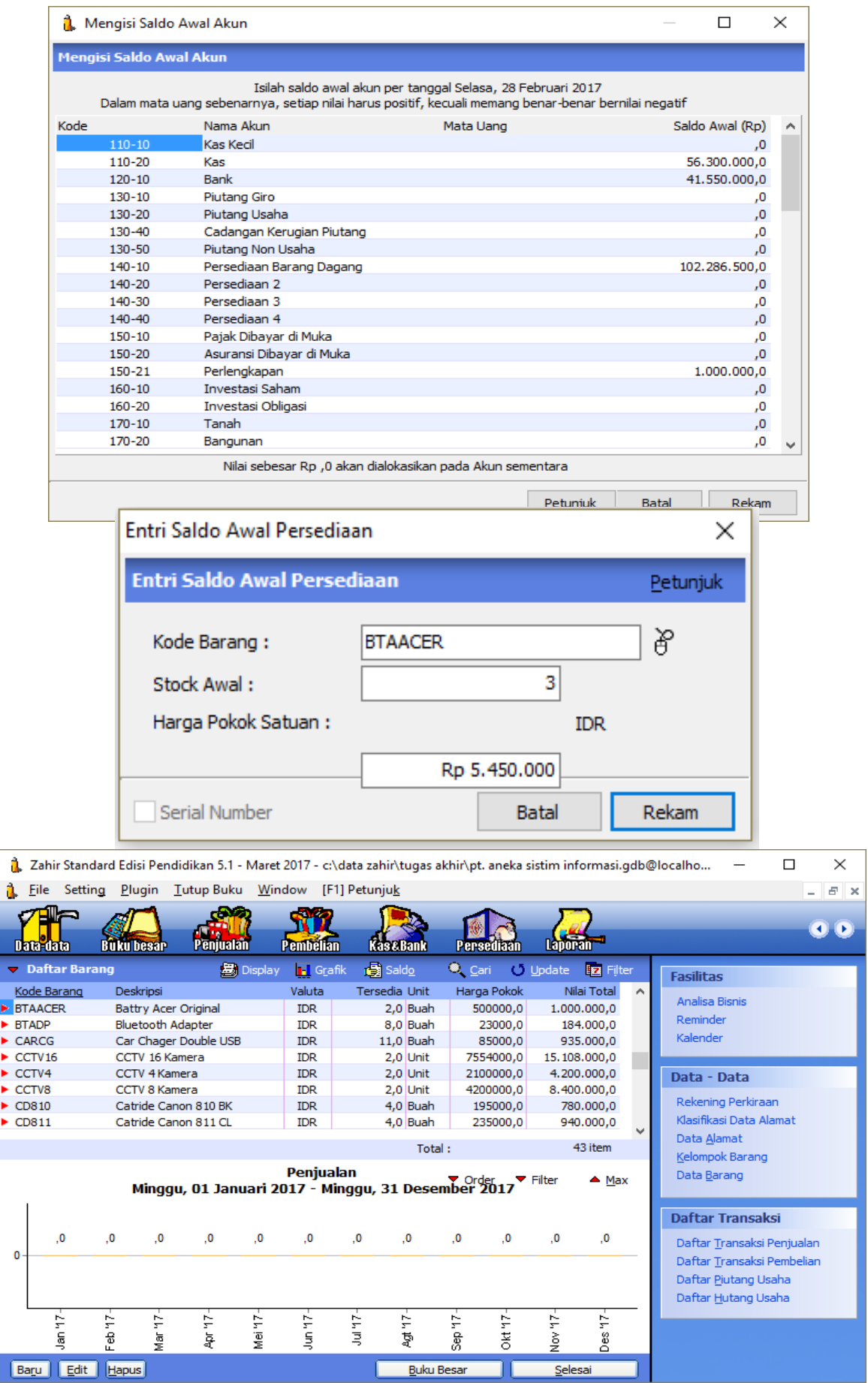

Sumber : Data Pengolahan Zahir 5.1 (2017)

Gambar 5. Input Persediaan, Setup Saldo Awal Dan Entri Saldo Awal Persediaan

\section{Input Data Transaksi}

Input data transaksi dapat dilakukan dengan cara memilih modul sesuai dengan transaksi yang terjadi. Adapun transaksi yang terjadi pada perusahaan diantaranya adalah : 
1. Tanggal 1 Maret 2017 Diterima service Program Ulang Asus dan HP dari Ibu Kiki @ Rp 150.000 dibayar secara tunai dengan nomor invoice 02-799.

Berdasarkan Gambar 6, maka instruksi pengisian adalah Pilih Modul Penjualan >> pilih Pengiriman Barang (Invoicing) >> berita tanda ceklis pada checkbox Jasa >> klik Rekam jika sudah selesai input data penjualan.

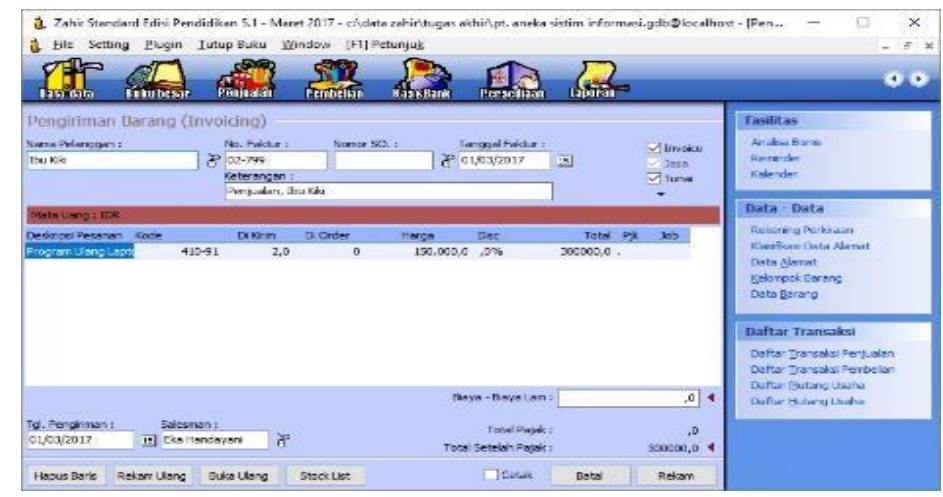

Sumber : Data Pengolahan Zahir 5.1 (2017)

Gambar 6. Data Transaksi Tanggal 01 Maret 2017

2. Tanggal 2 Maret 2017 Diterima service dari bapak Sutrisno pemasangan Printer canon M327 Rp 250.000 penjualan Catridge Canon 810 BK Rp 255.000 dan Catridge Canon 811 CL Rp 275.000 secara tunai nomor invoice 02-809.

Gambar 7 memberikan hasil dari proses input dengan acuan, Pilih Modul Penjualan > p pilih Pengiriman Barang (Invoicing) >> klik Rekam jika sudah selesai input data penjualan.

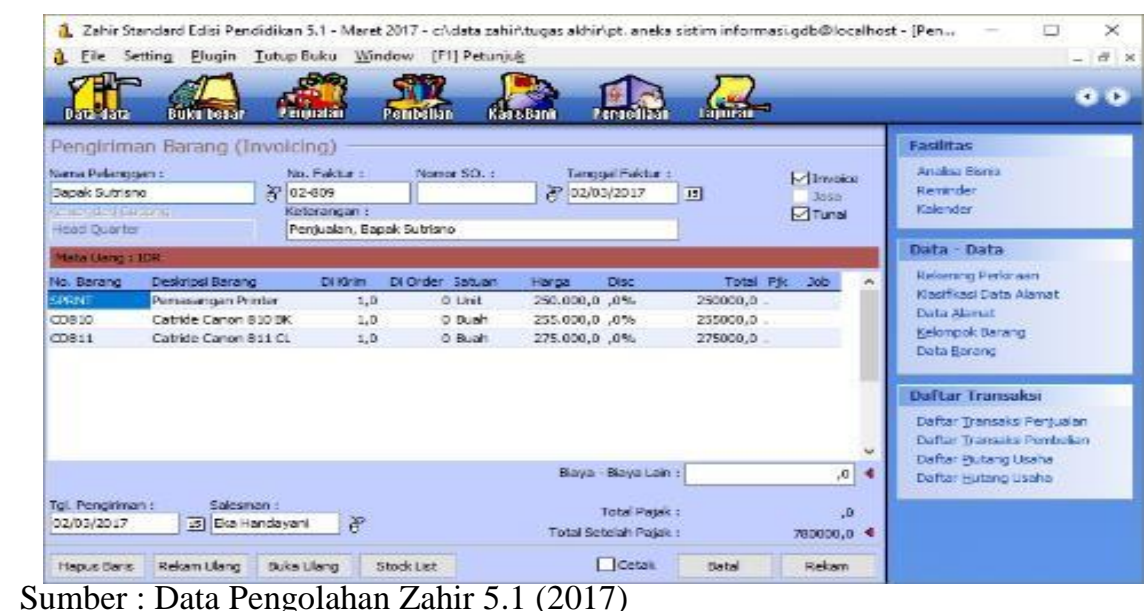

Gambar 7. Data Transaksi Tanggal 02 Maret 2017

\section{Laporan}

Hasil laporan keuangan pada perusahaan yang bersumber dari proses input transaksi menggunakan aplikasi Zahir Accounting adalah seperti pada tampilan Gambar 8 Laporan Laba Rugi, Pilih Modul Laporan >> pilih Laporan Laba Rugi >> klik maka akan tampil laporan yang diinginkan. 


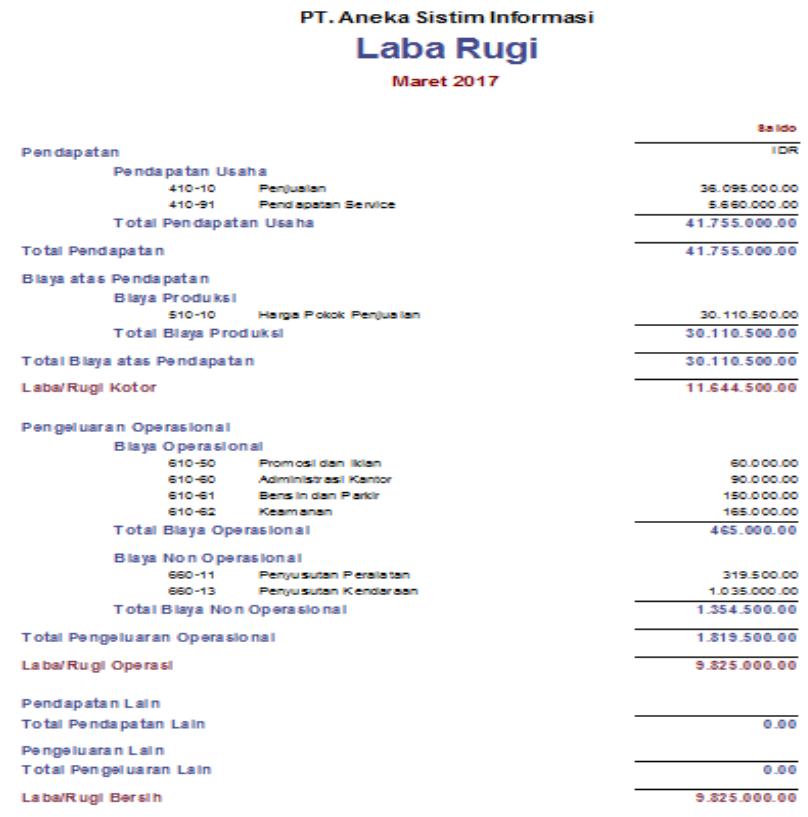

Sumber : Data Pengolahan Zahir 5.1 (2017)

Gambar 8 Laporan Laba Rugi

Gambar 9 Laporan Neraca, Pilih Modul Laporan >> pilih Laporan Neraca >> klik maka akan tampil laporan yang diinginkan.

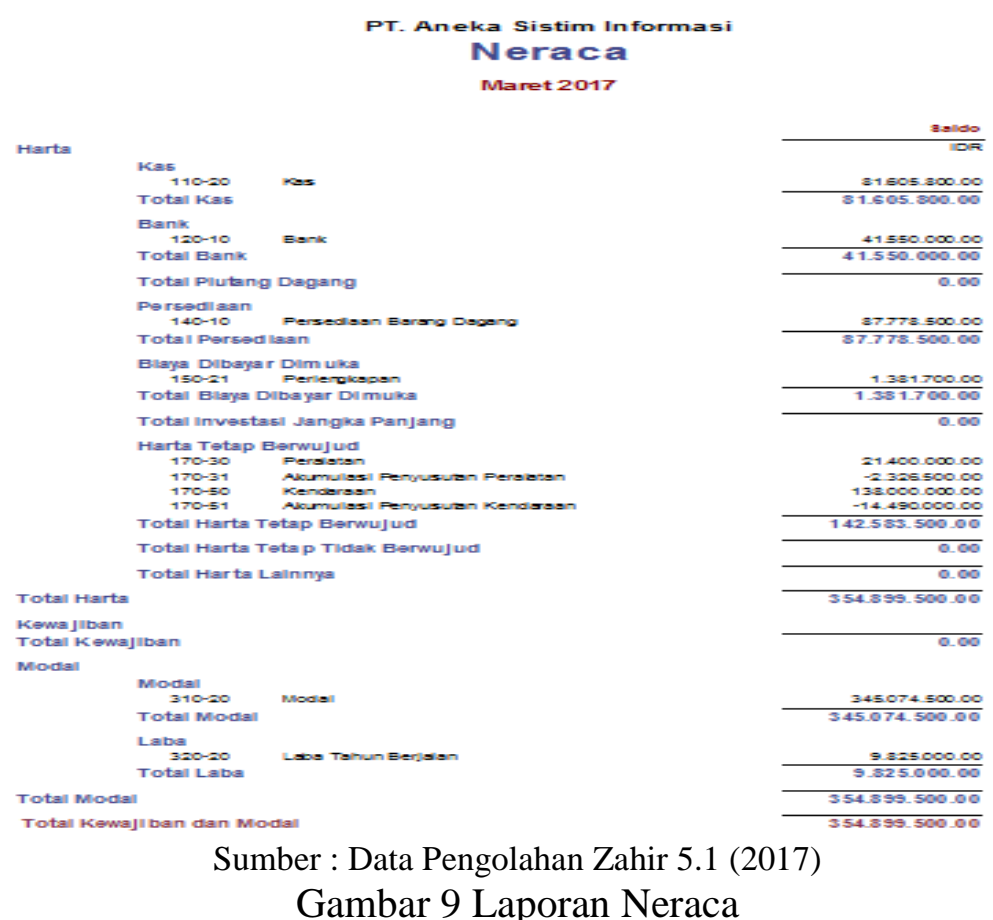

Gambar 9 Laporan Neraca

Gambar 10 Laporan Arus Kas, Pilih Modul Laporan >> pilih Laporan Arus Kas >> klik maka akan tampil laporan yang diinginkan. 


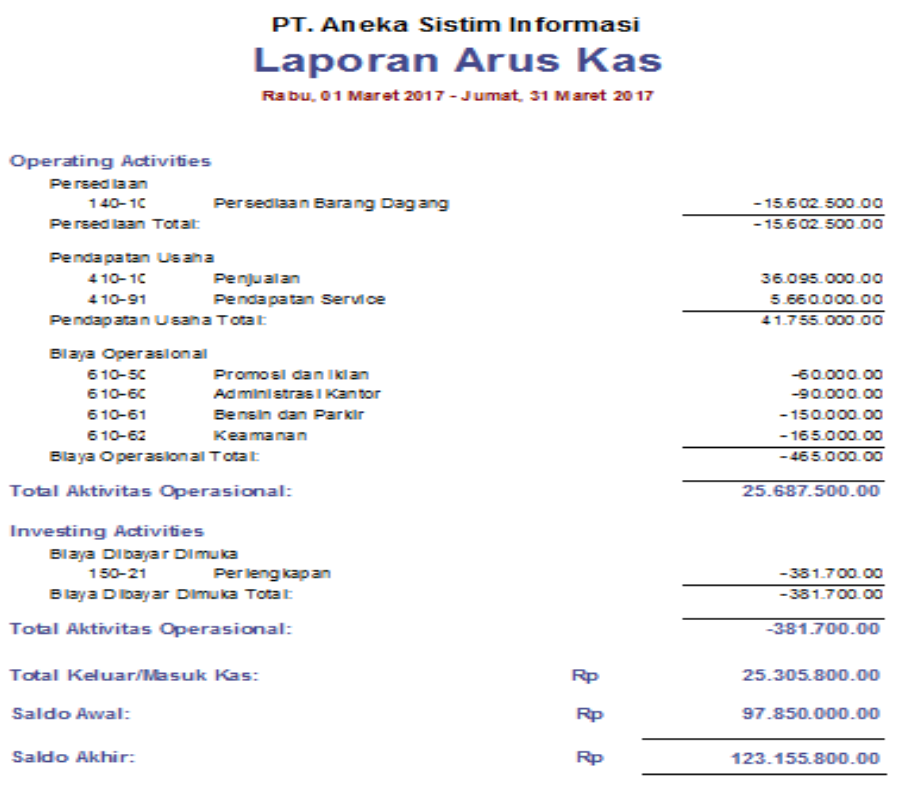

Sumber : Data Pengolahan Zahir 5.1 (2017)

Gambar 10 Laporan Arus Kas

Dari hasil pengolahan data dengan aplikasi komputer akuntansi dalam hal ini Zahir Accounting sebagai Software Akuntansi, maka untuk memperoleh kecepatan dan ketepatan dalam membuat laporan keuangan sudah tidak ada kata kompromi lagi. Antara Software akuntansi dan Excel keduanya baik dan memiliki fungsinya masing-masing yang unik dan apabila benar memasukan data maka hasil yang diperoleh akan sama, namun semakin kompleks aktivitas transaksi akan semakin tinggi kebutuhan terhadap Software akuntansi. Adapun yang menjadi perbedaan adalah dalam penggunaan rumus perhitungan Excel yang harus dibuat terlebih dahulu, sedangkan perhitungan Software Akuntansi sudah tersedia pada program aplikasi yang sudah siap pakai.

A. Rumus Perhitungan Excel melalui tahap :

1. Membuat rumus, jurnal dengan penghitungan diskon dan biaya serta rumus untuk menghitung harga pokok persediaan.

2. Merekonsiliasi bank karena harus mengeliminasi nilai yang tidak cocok lalu membuat jurnal penyesuaian, menghitung penyusutan harta tetap secara manual.

3. Membuat jurnal khusus yang menyebabkan adanya buku besar pembantu dan memposting lagi jurnal ke dalam buku besar dan pastinya sangat banyak jurnal yang harus diposting satu per satu.

4. Membuat Neraca Lajur untuk mencatat jurnal penyesuaiannya, mencatat jurnal pembalik saat tutup buku dilakukan serta membuat rumus dan menghitung secara manual rasio kinerja keuangan.

B. Perhitungan Software Akuntansi

Pada sub bab 4.2 hasil perhitungan dapat terlihat manfaatnya yaitu :

1. Penggunaan perangkat lunak aplikasi maka tidak perlu lagi harus mengingat dan membuat rumus-rumus seperti excel karena rumus sudah ada dalam program aplikasi.

2. Proses input data pendukung dan transaksi adalah langsung pada form yang tersedia. Kemudian sistem akan memproses secara otomatis dalam hitungan detik dan bekerja jauh lebih cepat dan makin mudah.

3. Laporan keuangan yang dihasilkan siap sedia dan langsung jadi.

4. Keputusan bisnis dapat langsung cepat ditetapkan. 


\section{KESIMPULAN DAN SARAN}

\subsection{Kesimpulan}

Hasil penelitian perihal adopsi penggunaan perangkat lunak aplikasi komputer akuntansi pada uraian pembahasan, maka dapat disimpulkan :

1. Pengolahan data transaksi akuntansi berbasis komputer dalam hal ini mengadopsi aplikasi komputer akuntansi dapat mengurangi kesalahan-kesalahan yang terjadi contohnya mengurangi resiko salah pencatatan nomor bukti.

2. Penerapan aplikasi komputer akuntansi dapat membantu mempermudah pengolahan data akuntansi dan menyajikan laporan keuangan secara cepat, tepat, efektif dan efisien. Selain itu aplikasi ini memiliki tingkat keamanan yang cukup valid dibanding dengan pengolahan data akuntansi secara manual.

3. Zahir Accounting dapat diaplikasikan pada perusahaan kecil maupun berskala besar dan dapat dipelajari dengan mudah tanpa harus memiliki keahlian dalam bidang akuntansi.

\subsection{Saran}

Adapun saran terkait pengembangan penelitian selanjutnya dalam penerapan aplikasi akuntansi berbasis komputer ini adalah meluaskan cakupan pembahasan sampai mengenai setup saldo hutang, saldo piutang, penjualan maupun pembelian secara kredit dan pembayaran menggunakan giro.

\section{DAFTAR PUSTAKA}

Fitria, Dina. (2014). Buku Pintar Akuntansi untuk Orang Awam dan Pemula. Jakarta

Timur: Lakkar Aksara.

Himayati. (2008). Eksplorasi Zahir Accounting. Jakarta: PT. Elex Media Komputindo. Manurung, Elvy Maria. (2011). Akuntansi Dasar (untuk Pemula). Jakarta: Erlangga. Puspitawati, Lilis, Sri Dewi Anggadini. (2011). Sistem Informasi Akuntansi. Yogyakarta:

Graha Ilmu. 